\title{
The Proposed Implementing Agreement: Options for Coherence and Consistency in the Establishment of Protected Areas beyond National Jurisdiction
}

\author{
Dire Tladi* \\ Professor of International Law, University of Pretoria, Hatfield, Pretoria 0028, South Africa
}

\begin{abstract}
The purpose of this article is to provide initial thoughts on potential conflicts between the mandates of Regional Fisheries Management Organizations (RFMOs) and any mechanisms for establishing Marine Protected Areas in the high seas and how these conflicts might be avoided. The article addresses first, whether the fears that may exist concerning the conflicts are, as a matter of international law, real and to the extent that they are real, how an Implementing Agreement (IA) might be shaped to avoid them. As the article is intended to provide only initial thoughts, the range of RFMOs and possible conflicts are only illustrative and are not intended to be comprehensive. With the potential conflicts in mind, the article then provides, in the third section, possible approaches that the drafters of the IA could adopt to avoid and/or mitigate against them. Finally, the article offers some concluding remarks.
\end{abstract}

\section{Keywords}

Law of the Sea Convention - high seas - Conservation - sustainable use - biodiversity - Implementing Agreement - regional fisheries management organizations (RFMOs) - marine protected areas

\section{Introduction}

On 19 June 2015, the General Assembly of the United Nations (hereinafter the 'General Assembly') adopted a Resolution providing for an intergovernmental conference to negotiate a possible Implementing Agreement, referred to as an 'international legally binding instrument' (hereinafter the 'IA'), under the UN Convention on the Law of the Sea (hereinafter the 'Convention') ${ }^{1}$ on the Conservation and Sustainable Use of Marine Biological Diversity in Areas Beyond National Jurisdiction. ${ }^{2}$ The Resolution also provides for a preparatory committee 'to make substantive recommendations' on the elements of such a proposed IA. ${ }^{3}$

\footnotetext{
* Member of the United Nations Commission on International Law. I wish to express my appreciation to Vita Onwuasoanya, Kristina Gjerde, Alexis Jackson, Andrew Friedman, Paulus Tak and Duncan Currie for their helpful comments on earlier drafts of this article. The flaws in the arguments and the errors remain entirely mine. This paper draws on the collaborative work of the author in various projects designed to reflect on what a possible Implementing Agreement under the Law of the Sea Convention might look like.

${ }^{1}$ United Nations Convention on the Law of the Sea (Montego Bay, 10 December 1982, in force 16 November 1994) 1833 UNTS 3.

${ }^{2}$ Paras. 1(k) and 2 of UN General Assembly Resolution on the Development of an International Legally Binding Instrument under the United Nations Convention on the Law of the Sea on the Conservation and Sustainable Use of Marine Biological Diversity of Areas Beyond National Jurisdiction, (A/Res/69/292), 19 June 2015.

${ }^{3}$ Ibid., at para $1(\mathrm{~b})$.
} 
The adoption of the Resolution by the General Assembly marked the end of a protracted and complicated process within the General Assembly, but also the beginning of a new, potentially more complicated process. It marked the end of the discussions within the UN Ad Hoc Informal Working Group to Study Issues Relating to the Conservation and Sustainable Use of Marine Biological Diversity in Areas Beyond National Jurisdiction (hereinafter the 'ad hoc working group'). ${ }^{4}$ In the course of the deliberations, spanning a decade, the ad hoc working group focused its discussions on two, interrelated issues, namely the legal regime applicable to marine genetic resources on the deep seabed and the question of conservation of marine biological diversity. ${ }^{5}$ Various aspects of the discussions have been considered by the author in other publications and will consequently not be repeated here. ${ }^{6}$

The question of fishing activities, in particular the potential relationship between Regional Fisheries Management Organizations (hereinafter 'RFMOs') and the IA, arises in relation to the second of the interrelated issues, namely conservation measures in areas beyond national jurisdiction. Conservation issues, in the context of the deliberations of the ad hoc working group and the future negotiations of an IA, are described as "measures such as area-based management tools, including marine protected areas, [and] environmental impact assessments". ${ }^{7}$ To the extent that the IA would create an institutional mechanism for the establishment of marine protected areas (hereinafter 'MPAs') that could have an impact on fishing activities within those areas, questions may validly arise concerning the relationship between such an institutional mechanism and the mandate of RFMOs in any given area beyond national jurisdiction. For example, would the decision to establish an MPA in areas under the management of an RFMO, including by providing for 'no-take zones, interfere with the mandate of the said RFMO? Would the validity of an MPA in areas beyond national jurisdiction be dependent on the 'blessings' of the competent RFMOs? Would the establishment of MPAs without the consultation or cooperation of relevant RFMOs necessarily lead to a conflict of norms not readily resolvable by recourse to the rules of international law?

The purpose of this article is to provide initial thoughts on potential conflicts between the mandates of RFMOs and any mechanisms for establishing MPAs in the high seas and how these conflicts might be avoided. The article addresses first, whether the fears that may exist concerning the conflicts are, as a matter of international law, real and to the extent that they are real, how an IA agreement might be shaped to avoid them. The next section describes the conflicts that might arise. This is done principally by considering the scope of the proposed IA in relation to fisheries, as well as the mandates of various RFMOs. As the article is intended to provide only initial thoughts, the range of RFMOs and possible conflicts are only illustrative and are not intended to be comprehensive. With the potential

\footnotetext{
${ }^{4}$ The ad hoc working group was established pursuant to para. 73 of UN General Assembly Resolution on Oceans and the Law of the Sea, (A/Res/59/24), 4 February 2004.

${ }^{5}$ The issues were interrelated in both a formal and a substantive sense. They were interrelated in the formal sense in that the participants agreed that these two issues will be "addressed together and as a whole". See para (b) of the Recommendations of the Ad Hoc Open-ended Informal Working Group to Study Issues Relating to the Conservation and Sustainable Use of Marine Biological Diversity Beyond Areas of National Jurisdiction, Annex to the UN General Assembly on Oceans and the Law of the Sea (A/Res/66/231), 24 December 2011. See also para 162 of The Future We Want (A/Res/66/288), 27 July 2012. But the two issues were also substantively interrelated in that both pose a challenge to the ever-eroding notion that the freedom of the high seas is the fundamental principle of ocean governance.

${ }^{6}$ For the most recent publications by the author on the subject see D. Tladi, 'State Practice and the Making and (Re) Making of International Law: The Case of the Legal Rules Relating to Marine Biodiversity in Areas Beyond National Jurisdiction' (2014) 1 State Practice and International Law Journal 97-116; D.Tladi, ‘The Common Heritage of Mankind and the Proposed New Treaty on Biodiversity in Areas Beyond National Jurisdiction: The Choice Between Pragmatism and Sustainability' (2014) Yearbook of International Environmental Law (forthcoming).

${ }^{7}$ See para (b) of the Recommendations of the Ad Hoc Open-ended Informal Working Group to Study Issues Relating to the Conservation and Sustainable Use of Marine Biological Diversity Beyond Areas of National Jurisdiction (2011) (n 5) and para. 2 of General Assembly Resolution 69/292 (n 2).
} 
conflicts in mind, the article then provides, in its third section, possible approaches that the drafters of the IA could adopt to avoid and/or mitigate these conflicts. Finally, the article offers some concluding remarks.

\section{Potential Conflicts Between the Mandates of RFMOs and the Proposed IA}

\section{Fisheries and the Scope of the IA}

In many ways it can be, and has been, argued that the objectives of the proposed IA, insofar as it relates to the protection and conservation of marine biological diversity in areas beyond national jurisdiction, is unnecessary and will amount to duplication. The Convention already provides a duty on States to "protect and preserve the marine environment". ${ }^{8}$ To this end, the Convention requires States, individually or collectively, to take measures for the conservation of the marine environment. ${ }^{9}$ States are thus, already, obliged to adopt measures, individually or collectively, for the conservation of the marine environment and such measures could include, for example, MPAs. It is thus not necessary, so the argument goes, to adopt an IA for this purpose. This point has been made by those States that have not been supportive of an IA. ${ }^{10}$ The United States, in particular, has made the following observations:

The United States supports the establishment of MPAs in areas beyond national jurisdiction. This can already be done through cooperation among nations, including through existing regimes and otherwise, if States are willing to apply obligations relating to MPAs to their nationals and flagged vessels. ${ }^{11}$

It is certainly true that the Convention makes provisions for conservation measures; however, there appears to be consensus in academic literature that there has been increasing degradation of the marine

\footnotetext{
${ }^{8}$ See, e.g., Art 192 of the UN Convention on the Law of the Sea. It has been noted that, as quantitative matter, 46 of the 320 Articles of the Convention "are devoted to the protection of the marine environment". See C. Redgwell 'From Permission to Prohibition: The 1982 Convention on the Law of the Sea and the Protection of the Marine Environment,' in D. Freestone, R. Barnes and D. Ong (eds) The Law of the Sea: Progress and Prospects (Oxford: Oxford University Press, 2006) 180-191, at 180.

${ }^{9}$ See, e.g., Art. 194 (measures to prevent, reduce and control pollution of the marine environment), Art. 197 (cooperation on a global or regional basis), Art. 210 (pollution from land-based sources), Art. 211 (pollution from vessels) and Art. 212 (pollution from or through the atmosphere). Specifically with respect to areas beyond national jurisdiction, see Art. 117 (duty of states to adopt with respect to their nationals measures for the conservation of the living resources of the high seas), Art. 118 (cooperation of States in the conservation and management of living resources), Art. 145 (protection of the marine environment in the Area) and Art. 240 (general principles for the conduct of marine scientific research).

${ }^{10}$ See Para 81 of the Co-Chairs' Summary of the Discussions at the Ad Hoc Open-ended Informal Working Group to Study Issues Relating to the Conservation and Sustainable Use of Marine Biological Diversity Beyond Areas of National Jurisdiction (A/69/177), 25 July 2014 where "it was [further] observed that willing States were already capable of establishing marine protected areas on the high seas and the question was raised as to how a new agreement would overcome unwillingness on the part of some States to establish such areas beyond national jurisdiction."

${ }^{11}$ See Submission by the United States, Scope, Parameters and Feasibility of an International Instrument under the United Nations Convention on the Law of the Sea: Informal Working Document Compiling Views of Member States, Prepared in Accordance with General Assembly Resolution 68/70, Para 201, 4 December 2014, at 34 (on file with author). See also United States, Scope, Parameters and Feasibility of an International Instrument under the United Nations Convention on the Law of the Sea: Informal Working Document Compiling Views of Member States, Prepared in Accordance with General Assembly Resolution 68/70, Para 201, 11 March 2014, at 58 (on file with author).
} 
environment even post the Convention. ${ }^{12}$ As Gjerde has pointed out, notwithstanding the many provisions on conservation in the Convention, "fish stocks are declining", "there are rising biodiversity concerns" and "illegal, unreported and unregulated fishing activities are expanding." 13 Freestone is more direct. ${ }^{14}$ Having reflected on the major environmental challenges facing the post-Convention marine environment, he states that "the 1982 Convention regime has not lived up to expectations in terms of delivering the instruments of international cooperation and governance that UNCLOS III drafters may have intended." ${ }^{\prime 15}$ In another contribution, Gjerde and Rulska-Domino make the following observations:

areas beyond national jurisdiction (ABNJ) contain perhaps the largest reservoir of biodiversity (the largest of species, communities and ecosystems) left on earth, but are under extreme pressure. Evidence of this impact may be found in the near collapse of commercially valuable fish stocks .... [and other impacts]. Despite the exponential increase of threats, the rules of and regulations for the conservation and sustainable use of marine biodiversity ... have not kept pace. ${ }^{16}$

Thus, although there certainly are provisions on the protection of the marine biodiversity in areas beyond national jurisdiction, the current state of the marine environment, including the ongoing loss of marine biodiversity and depletion of a number of fish stocks at a high rate, suggests that these provi sions are not sufficient. One of the main reasons for the current ocean governance's inability to sufficiently address the degradation of the marine environment is the excessive emphasis on the Grotian notion of the freedom of the seas which, in essence, re-enacts Hardin's tragedy of the commons. ${ }^{17}$ In this connection, the United States has noted that the proposed IA could not remedy this problem because States that decide to adopt MPAs "cannot...obligate unwilling States to accept the designation of an MPA beyond national jurisdiction and abide by its management measures." 18

In a sense, the proposed IA, similarly to the Fish Stocks Agreement, ${ }^{19}$ would seek to give effect to the environmental obligations in the Convention by constraining, to some extent, the freedom of the high seas. ${ }^{20}$ The IA would also seek to provide detail to the environmental protection obligations in the Convention which are largely regarded as too general and too vague, and lacking an institutional framework for implementation. ${ }^{21}$ In the context of an MPA, an IA would spell out the requirements for when an MPA should be put in place, the decision-making processes for putting it in place and for the

\footnotetext{
${ }^{12}$ See, e.g., R. Jozan, J. Rochette and S. Sundar, 'Oceans: The New Frontier' in P. Jacquet, R.K. Pachauri and L. Tubiana (eds) Oceans: The New Frontier (Paris: The Energy and Resources Institute, 2011), 17-24, at 20.

${ }^{13}$ K. M. Gjerde, 'High Seas Management under the Convention on the Law of the Sea' in Freestone et al., (n 8), 281-307at 281.

${ }^{14}$ D. Freestone, 'International Governance, Responsibility and Management of Areas Beyond National Jurisdiction' (2012) 27 International Journal of Marine and Coastal Law 191-204.

15 Ibid, at 194 .

${ }^{16}$ K. M Gjerde and A. Rulska-Domino, 'Marine Protected Areas beyond National Jurisdiction: Some Practical Perspectives for Moving Ahead' (2012) 27 International Journal of Marine and Coastal Law 351-373.

${ }^{17}$ See D. Tladi 'Oceans Governance: A Fragmented Regulatory Framework?' in Jacquet et al. (n 12), 99-110 at 103.

${ }^{18}$ United States Submission, March 2014 (n 11), at 58.

${ }^{19}$ Agreement for the Implementation of the Provisions of the Convention on the Law of the Sea of 10 December 1982 relating to the Conservation and Management of Straddling Fish Stocks and Highly Migratory Fish Stocks (New York, 4 August 1995 in force 11 December 2001) 2167 UNTS 88.

${ }^{20}$ See, e.g., Art. 17 of the 1995 Agreement for the Implementation of the Provisions of the United Nations Convention on the Law of the Sea of 10 December 1982 Relating to the Conservation and Management of Straddling Fish Stocks and Highly Migratory Fish Stocks. See also Freestone (n 14), at 200-201, discussing what he terms "conditional freedom of the seas".

${ }^{21}$ See, e.g., R. Barnes, 'The Convention on the Law of the Sea: An Effective Framework for Domestic Fisheries Conservation?' in Freestone et al. (n 8), 233-260, at 233.
} 
identification of specific measures to be adopted, and the legal effects of such an MPA. Whereas, as a matter of international law, these legal effects could apply only to States Parties of the IA, the existence of the IA would obviate the necessity for specific and individual State consent to each individual MPA established in areas beyond national jurisdiction. At any rate, the mere existence of a framework could result in an increased rate in the creation of high seas MPAs.

The question of whether fishing activities should be excluded from the proposed new IA first arose during what were referred to as "scope, parameters and feasibility" discussions. In December 2013, while the ad hoc working group was considering the possibility of an IA, the General Assembly requested the ad hoc working group to make recommendations to the Assembly on the "scope, parameters and feasibility of an international instrument under the Convention.",22 During the ad hoc working group's consideration of the scope, parameters and feasibility of an IA, several States suggested excluding fisheries from the scope of the debate in their entirety, as there was already a regime in place governing fishing-related activities. Iceland, for example, warned that "care should be taken not to reopen issues that are already subject to a sufficient legal regime". ${ }^{23}$ In particular, Iceland identified 'fisheries' as a regime which is subject to "the legal regime of the [Convention] that was complemented by the [Fish Stocks Agreement]," both of which "provide the framework for work of RFMOs". ${ }^{24}$ In a similar vein, concerns have been raised within the Informal Consultations of States Parties to the Fish Stocks Agreement about the potential of the proposed IA to undermine the Fish Stock Agreement. ${ }^{25}$

Whereas it is true that fisheries are governed by a regime underpinned by the Fish Stocks Agreement, the effectiveness of this regime greatly varies due to lack of coordination and integration. ${ }^{26}$ More importantly, the scope of the Fish Stocks Agreement is limited to highly migratory and straddling fish stocks and does not extend to the management of broader biodiversity issues. Yet fishing constitutes one of the more serious threats to marine biodiversity in areas beyond national jurisdiction as a result of both overfishing and the use of destructive fishing practices. ${ }^{27}$ The scope of the Fish Stocks Agreement is limited by its terms to the "conservation and sustainable use of straddling fish stocks and highly migratory fish stocks". ${ }^{28}$ The Agreement is thus fisheries-specific, i.e., its scope does not extend to biodiversity in general. Although the Fish Stocks Agreement is limited to fish stocks, and in particular to straddling and highly migratory fish stocks, the Agreement requires, for example, the protection of "biodiversity in the marine environment" as a means to achieve this objective. ${ }^{29}$ It does not spell out how biodiversity is to protected, but the inclusion of the general obligation to protect biodiversity in the context of conserving fish stocks is an important illustration of the link between the fishing activities and the protection of the marine environment. Excluding fishing activities from the scope of an IA designed to address broader conservation of marine biological diversity in areas beyond national jurisdiction would thus make little sense. That said, the concerns raised about possible conflicts cannot be ignored. As Canada noted in its submissions on the scope, parameters and feasibility of an IA, the challenge in

\footnotetext{
${ }^{22}$ Para. 198 of the UN General Assembly Resolution on Oceans and the Law of the Sea (A/Res/68/70), 9 December 2013.

${ }^{23}$ Submission by Iceland in the Informal Working Document of March 2014 (n 11) at 31.

${ }^{24}$ Ibid. See also Submission by Japan in the Informal Working Document of March 2014 (n 11) at 35.

${ }^{25}$ See Para 52 of the Eleventh Round of Informal Consultations of States Parties to the Agreement for the Implementation of the Provisions of the United Nations Convention on the Law of the Sea of 10 December 1982 relating to the Conservation and Management of Straddling Fish Stocks and Highly Migratory Fish Stocks, (ICSP11/UNFSA/INF.3), 14 May 2015, which states: "A delegation questioned how the implementing agreement being discussed within the context of the Ad Hoc Open-ended Informal Working Group to study issues relating to the conservation and sustainable use of marine biological diversity beyond areas of national jurisdiction would relate to the Agreement and whether such an implementing agreement could undermine the Agreement and affect fisheries."

${ }^{26}$ Gjerde and Rulska-Domino (n 16), at 356 et seq.

${ }^{27}$ Ibid., at 362 .

${ }^{28}$ See Arts. 2 and 3 of the Fish Stocks Agreement.

${ }^{29}$ See Art. 5 of the Fish Stocks Agreement.
} 
elaborating an IA covering fisheries is to "clearly identify how it would interact with existing international regimes". ${ }^{30}$ The United States, which has not been supportive of the elaboration of an IA, takes the view that if an IA were to elaborated, such an IA would need to cover fisheries, but has also stresses that to be effective, the IA would need to be based on "coordination with existing RFMOs". ${ }^{11}$ In order to assess the possible approaches to the design of the IA, it is important to have an understanding of the various mandates of RFMOs.

\section{Survey of Mandates of RFMOs}

A survey of the mandates of RFMOs reveals wide variations, in terms of both geographical scope and functional coverage. ${ }^{32}$ In terms of geographical scope, RFMOs are limited to a particular area of the ocean. The geographical scope of the International Commission for the Conservation of Atlantic Tunas (hereinafter 'ICCAT'), for example, is limited to the Atlantic Ocean. ${ }^{33}$ In many instances, the geographical scope of RFMOs is defined in terms of the parts of the ocean defined by latitude and longitude. $^{34}$ The geographical scope of the mandate of the Commission for the Conservation of Antarctic Marine Living Resources (hereinafter 'CCAMLR'), for example, is "the area south of $60^{\circ}$ South latitude and ... the area between that latitude and the Antarctic Convergence". ${ }^{35}$ Although there are many RFMOs covering different parts of the ocean, with varying degrees of overlap, some gaps in geographical coverage remain. ${ }^{36}$

In addition to geographical limitation, the mandates of RFMOs are very often generally limited to the management of a specific type of resource, in particular fisheries, and do not address marine biodiversity in general. In many instances, the RFMO is concerned with a particular type of fishery. ${ }^{37}$ Examples in this respect include ICCAT, the Indian Ocean Tuna Commission (hereinafter the 'IOTC') and the Inter-American Tropical Tuna Commission (hereinafter the 'IATTC'), whose functional scope

\footnotetext{
${ }^{30}$ Submissions by Canada in the Informal Working Document of December 2014 (n 11), at 12.

${ }^{31}$ Submission of the United States in the Informal Working Document of December 2014 (n 11).

${ }^{32}$ Gjerde and Rulska-Domino (n 16), at 363.

${ }^{33}$ See Art I of the International Convention for the Conservation of Atlantic Tunas, (Rio de Janeiro, 14 May 1996 in force 21 March 1969) 673 UNTS 63, (hereinafter 'ICCAT').

${ }^{34}$ For example, North East Atlantic Fisheries Commission is limited to "those parts of the Atlantic and Arctic Oceans and their dependent seas which lie north of $36^{\circ}$ north latitude and between $42^{\circ}$ west longitude and $51^{\circ}$ east longitude" and "that part of the Atlantic Ocean north of $59^{\circ}$ north latitude and between $44^{\circ}$ west longitude and $42^{\circ}$ west longitude". See Article 1(a) of the Convention on Future Multilateral Cooperation in North-East Atlantic Fisheries (London, 18 November 1980 in force 17 March 1982) 1285 UNTS 129. See also Art. I of the Convention on Future MultilateralCooperation in the Northwest Atlantic Fisheries establishing the Northwest Atlantic Fisheries Convention (NAFO), Ottawa, 24 October 1978 in force 1 January 1979) 1135 UNTS 369, and Art. 4 of the Convention on the Conservation and Management of Fishery Resources in the South East Atlantic Ocean, which established the Southeast Atlantic Fisheries Organization (SEAFO), (Windhoek, 20 April 2001 in force 13 April 2003), 2221 UNTS 189. See also Art 3 of the Convention on the Conservation and Management of Highly Migratory Fish Stocks in the Western and Central Pacific Ocean, (Honolulu, 5 September 2000 in force 19 June 2004) 2275 UNTS 43.

${ }^{35}$ See Art. I of the Convention for the Conservation of Antarctic Marine Living Resources, (Canberra, 20 May 1980 in force 7 April 1982), 1329 UNTS 48.

${ }^{36}$ Gjerde and Rulska-Domino (n 16) at 363. See, however, S. Cullis-Suzuki and D. Pauly 'Failing the High Seas: A Global Evaluation of Regional Fisheries Management Organization' (2010) 34 Marine Policy 1036-1042, at 1036, where it is stated that only a few areas of the ocean remain that are not the subject of an RFMO. See also D. Freestone, 'Fisheries, Commissions and Organizations' in Rudiger Wolfrum (ed.) Max Planck Encyclopaedia of Public International Law (2010, online edition), at 18, who states as follows: "Although the global network of tuna management commissions is quite comprehensive, there are a number of major gaps in the areas covered by the general fisheries commissions managing the conservation of high seas stocks of non-tuna species."

${ }^{37}$ Ibid., at 362 .
} 
concerns tuna and other species similar to tunas. ICCAT's mandate, for example, extends to "tuna and tuna-like fishes ... and other species of fishes exploited in tuna fishing". ${ }^{38}$ Article VI of the ICCAT provides for the establishment of panels on the basis of species in order to, inter alia, keep the species under review ${ }^{39}$ and make recommendations for joint action. ${ }^{40}$ To date, however, only four panels have been established, covering tropical tunas (yellowfin, bigeye and skipjack), northern temperate tunas (albacore and Atlantic blue fin), southern temperate tunas (albacore and southern bluefin) and other species (swordfish, billfish and small tunas, as well as sharks, seabirds, and other species commonly caught as bycatch in the tuna fisheries). ${ }^{41}$ Through these panels, Contracting Parties cooperate to optimize the exploitation of these species. Although ICCAT does seek to ensure, with various levels of success, that these species are not overexploited, it has no mandate to advance wider conservation objectives. For example, ICCAT will not designate an MPA in its Convention Area with the intent advance a wider environmental objective not directly linked to its mandate.

CCAMLR, though not technically an RFMO, provides a useful exception to the fisheries-specific management approach used by RFMOs. The objective of the CAMLR Convention is broadly 'the conservation of Antarctic marine living resources. ${ }^{42}$ Living resources are defined broadly to include, in addition to resources named specifically, "all other species of living organisms". ${ }^{43}$ More importantly, the CAMLR Convention adopts an ecosystem-based management approach, which the RFMOs generally do not. For example, the CAMLR Convention defines the Antarctic ecosystem as "the complex of relationships of Antarctic marine living resources with each other and with their physical environment."44 In general, however, the mandate of RFMOs is often limited in scope to fisheries, and in many instances, to specific types of fisheries; furthermore, the experience of the CCAMLR is not typical.

In the midst of the growing calls for an ecosystem approach to the management of the resources of the ocean, ${ }^{45}$ some RFMOs have referred to the need to take into account broader biodiversity concerns. The parties to the North East Atlantic Fisheries Commission (hereinafter 'NEAFC'), for example, in an interpretative declaration, have declared that in carrying out its mandate, the Commission "shall ... take due account of the impact of fisheries on other species and marine ecosystems." 46 However, a survey of measures adopted recently by NEAFC shows that it has generally maintained a sectoral fisheries-related mandate, with few exceptions. ${ }^{47}$ Among these is its recommendation with regard to vulnerable marine

\footnotetext{
${ }^{38}$ See Art. IV(1) of the ICCAT (n 33).

${ }^{39}$ Ibid, Art. VI(a) of the ICCAT.

${ }^{40}$ Ibid, Art. VI(b) of the ICCAT

${ }^{41}$ See for the establishment of the Panels, Item 17 (Establishment of Panels and Date and Place of their Meetings), Report of the First Meeting of the International Commission for the Conservation of Atlantic Tunas, Rome, December 1969, FAO Fisheries Reports, No. 84.

${ }^{42}$ Article II(1) of the CAMLR Convention (n 35).

${ }^{43}$ Ibid, Article I(2) of the CAMLR Convention.

${ }^{44}$ Ibid, Article I(3) of the CAMLR Convention.

${ }^{45}$ See, e.g., para 171 of the UN General Assembly Resolution on Oceans and the Law of the Sea (A/Res/69/245). More specific to fisheries, see para. 7 of the UN General Assembly Resolution on Sustainable Fisheries, including through the 1995 Agreement for the Implementation of the Provisions of the United Nations Convention on the Law of the Sea of 10 December 1982 relating to the Conservation and Management of Straddling Fish Stocks and Highly Migratory Fish Stocks, and related instruments (A/Res/69/109), 9 December 2014, which states as follows: "Calls upon all States, directly or through regional fisheries management organizations and arrangements, to apply widely, in accordance with international law and the Code, the precautionary approach and ecosystem approaches to the conservation, management and exploitation of fish stocks".

${ }^{46}$ See NEAFC Declaration on the Interpretation of the Convention on the Future Multilateral Cooperation in North East Atlantic Fisheries, (AM 2005/21), available at http://www.neafc.org/system/files/London-Declaration.pdf (last accessed 8 September 2015).

${ }^{47}$ See for a list of measures adopted by NEAFC: http://www.neafc.org/managing_fisheries/measures/current (last accessed on 8 September 2015)
} 
ecosystems ${ }^{48}$ This recommendation is aimed at protecting the broader environment by putting in place fisheries-specific measures, in particular restrictions on bottom-fishing, and was inspired by the provisions of UN General Assembly Resolution 61/105 on bottom fishing. ${ }^{49}$

The Western and Central Pacific Fisheries Commission (hereinafter the 'WCPFC'), "applies to all stocks of highly migratory fish within the Convention Area except sauries". 50 Although the members of the WCPFC are called upon to "protect biodiversity in the marine environment", ${ }^{51}$ their convention does not operationalize this broad aspiration. Instead, its primary objective is "to ensure, through effective management, the long-term conservation and sustainable use of highly migratory fish stocks". 52 Indeed, even the scope of application is not biodiversity and the marine environment, but "stocks of highly migratory fish within the Convention Area'. ${ }^{53}$ The mandate of the South Pacific Regional Fisheries Management Organization (hereinafter the 'SPRFMO') is similarly fisheries-specific, but provides some elements of broader marine environmental conservation. ${ }^{54}$ Although the Convention on the Conservation and Management of High Seas Fishery Resources in the South Pacific Ocean refers in its objective to an "ecosystem approach" and safeguarding the "marine ecosystem in which [fishery] resources occur", these are in relation to its primary objective of "fisheries management" and "the long-term conservation and sustainable use of fishery resources." $" 55$

This very brief survey should illustrate that although there are many RFMOs, their functional mandates are limited and, to some extent, even their geographical scope is limited. In particular, not all geographical areas are covered and not all components of biodiversity are covered. More importantly, reliance on RFMOs, which are fisheries-specific, and in many cases limited to specific types of fisheries, entrenches the sectoral approach and may be inconsistent with an ecosystem-based approach. To these limitations of scope one might also add an issue not covered in this survey, namely the varying degrees of effectiveness of RFMOs, ${ }^{56}$ which may provide an additional reason for a more coherent and uniform

\footnotetext{
${ }^{48}$ See Recommendation on the protection of vulnerable marine ecosystems in the NEAFC Regulatory Area, Recommendation 19:2014, as amended by Recommendation 9:2015, available at http://www.neafc.org/managing_fisheries/measures/current (last accessed 8 September 2015). Whereas, for example, the Recommendation to Adopt Conservation and Management Measures for Deep-Sea Shark in the NEAFC Regulatory Area from 2013, Recommendation 7:3013, http://www.neafc.org/managing_fisheries/measures/current (last accessed 25 September 2015), is technically not fisheries-specific, it remains a single-species and not general marine biodiversity-related recommendation.

${ }^{49}$ See para. 83 of the UN General Assembly Resolution on Sustainable Fisheries, including through the 1995 Agreement for the Implementation of the Provisions of the United Nations Convention on the Law of the Sea of 10 December 1982 relating to the Conservation and Management of Straddling Fish Stocks and Highly Migratory Fish Stocks, and related instruments, (A/Res/61/105), 8 December 2006.

${ }^{50}$ Art. 3 of the Convention on the Conservation and Management of Highly Migratory Fish Stocks in the Western and Central Pacific Ocean (n 34).

${ }^{51}$ See ibid., at Art. 5(f).

52 Ibid. at Art. 2.

${ }^{53}$ Ibid. at Art 3(3).

${ }^{54}$ The SPRFMO is established under the Convention for the Conservation and Management of High Seas Fishery Resources in the South Pacific Ocean, November 2009, available at https://www.sprfmo.int/assets/BasicDocuments/Convention-and-Final-Act/Convention-web.pdf (last accessed 9 September 2015).

${ }^{55}$ Ibid. at Art 2. Article 2 provides in whole as follows: "The objective of this Convention is, through the application of the precautionary approach and an ecosystem approach to fisheries management, to ensure the longterm conservation and sustainable use of fishery resources and, in so doing, to safeguard the marine ecosystems in which these resources occur." (emphasis added).

${ }^{56}$ See, e.g., Cullis-Suzuki and Pauly (n 36), for a study on the effectiveness of RFMOs. Having considered both theoretical and practical effectiveness, the authors, at 1042, reach the following conclusion: "In this regard, RFMOs have failed. It is evident from the results here that the priority of RFMOs - or at least of their member countries has been first and foremost to guide the exploitation of fish stocks. While conservation is part of nearly all of their mandates, the have yet to demonstrate a genuine commitment to it on the water." See also Freestone (n 34) at para 33.
} 
approach of a global IA. Still, the RFMOs are a reality, and to be successful, the design of the IA has to take into account the existence of RFMOs and should promote coherence by avoiding conflict. An IA, properly designed, would serve to provide an integrated and more uniform approach to the establishment of MPAs, which cannot be achieved through sectoral RFMOs.

\section{Possible Approaches for Achieving Coherence}

\section{Range of Options: Choice between Deference and Non-recognition?}

There are a number of ways that the design of a new IA for the conservation and sustainable use of marine biodiversity in areas beyond national jurisdiction can take into account the existence of RFMOs. One option, the deferential or maximalist approach, would be for the responsibility for the establishment of MPAs in areas beyond national jurisdiction to be placed with the RFMOs themselves. The other side of the spectrum, the minimalist or non-recognition approach, would simply place the responsibility of establishing MPAs in areas beyond national jurisdiction in another, possibly new, entity without a formal role for the RFMOs in that process. Between these two extremes a continuum of options is available to the negotiators of the IA.

The deferential approach, although attractive because of reliance on existing mechanisms, is not without its problems. First, if the management measures adopted under the RFMO were applicable only to members of the respective RFMOs, then the deferential approach would mean the continuation of the status quo. In this respect, as noted by the United States in the reference above, States are already free to adopt MPAs and an IA that simply recognizes, without more, the ability of States to expand the competence of their RFMOs and then adopt measures with respect to their members, would be without any real effect. ${ }^{57}$ Yet a deferential approach which extends the applicability of measures adopted by RFMOs to other States is problematic. Such an approach first assumes that such an expanded mandate is politically feasible or desirable. It would also raise the legal problem of the unwilling State identified by the United States, i.e., "[w] hat willing States cannot do is obligate unwilling States to accept the designation of an MPA beyond national jurisdiction and to abide by its management measures." 58 It appears that this same concern caused Argentina to state that the terms of reference of an intergovernmental conference "must explicitly rule out that such functions ...could be in the care of entities with limited participation such as RFMOs."59 The approach would be legally problematic, because, as a matter of international law, States cannot be bound by rules to which they have not agreed. This legal problem could be overcome by adopting the Fish Stocks Agreement approach, i.e., ratification of the IA amounts to consent to abide by the management of RFMOs, including those to which a State may not be a member.

However, the solution of consent-through-ratification-of-the-IA would itself raise a number of difficulties. First of all, many States are likely to find such an approach unacceptable and indeed this may be one of the reasons for the slow rate of ratification of the Fish Stocks Agreement. Second, the legitimacy of a decision to establish a 'globally' binding MPA - or at least an MPA binding on all Parties to the IA - would likely depend on consistent, science-based criteria. Yet it cannot be assured that RFMOs would all apply consistent, science-based criteria. Moreover, this deferential approach would still suffer from the drawbacks of scope and inconsistency described above. Finally, and perhaps more importantly, this approach would still be largely dependent on a sectoral approach, which is one of the problems that the IA is supposed to remedy. ${ }^{60}$

\footnotetext{
${ }^{57}$ United States Submission, March 2014 (n 11), at 58.

${ }^{58}$ United States Submission, December 2014 (n 11), at 34.

59 Argentina Submission (courtesy translation) in the Informal Working Document of December 2014 (n 11 ), at 4.

${ }^{60}$ See in this regard, the submission by Australia, in the Informal Working Document of December 2014 (n 11), at 5 , which notes that although there are existing mechanisms, "the coordination of activities across sectors and the
} 
The non-recognition approach would require either the creation of a new entity, or the expansion of the mandate of an existing entity, with the mandate to establish MPAs with measures binding on all State Parties to the IA, without the involvement of RFMOs (and other organizations with sectoral mandates in areas beyond national jurisdiction). This approach is attractive because, depending on the decision-making criteria, it avoids inconsistency and promotes an ecosystem approach. Nonetheless, it risks the possibility of conflict between the measures adopted by the mechanism of the IA and those adopted by the RFMOs. At any rate, General Assembly Resolution 69/292 already sets out that a basic principle to govern the negotiations of a new IA will be that the IA "should not undermine existing relevant legal instruments and frameworks and relevant global, regional and sectoral bodies." 61

\section{Recognizing without Deferring to RFMOs: An Illustration}

It should be clear from the above analysis that the optimal approach will be that which recognizes the mandate (and even importance) of RFMOs without deferring to them. One option would be the creation of a 'new entity' (or structure) with some role for RFMOs at both the decision-making and implementation phases of MPA establishment. It is apposite to state here, although this falls outside the scope of this article, that a new entity does not mean a new international organization. Whereas a new international entity might well be a new international organization, there is clearly no appetite for the establishment of a new international organization.

A new entity could be comprised simply of a secretariat, which some States have argued could be the UN's Division for Ocean Affairs and the Law of the Sea (known as 'DOAOLOS'), a legal, scientific and/or technical commission (hereinafter the 'LSTC') and a decision-making body in the form of, for example, a Conference of the Parties (hereinafter the 'COP'). Much of how the structure would, in practice, function would depend on, for example, the rules pertaining to (procedural) decision-making, and the (substantive) criteria for the establishment of MPAs. These issues, important though they are, fall outside the scope of this article. It is important also to emphasize that, this being only an illustrative approach, there may be variations to this basic structure.

Bearing in mind the illustrative purpose of this paper, the COP might take decisions on the establishment of an MPA on the basis of a recommendation by the LSTC. The key question, as regards the relationship between an IA and RFMOs, is where, in this decision-making chain, RFMOs would fit. The agreement could make provision for the interaction, first and foremost, between the secretariat of the COP, in this case DOALOS, and the secretariat of the RFMOs. Second, in addition to States Parties to the IA, RFMOs (and other competent organizations) should be permitted to submit proposals for MPAs (and attendant measures) to the decision-making bodies. ${ }^{62}$ Allowing an RFMO to make proposals for an MPA, in addition to building solid relationships of cooperation, will also enhance the possibility for compliance with any decision to establish an MPA as proposed, at least from the members of that particular RFMO.

Third, during its consideration of any proposal for an MPA, the LSTC should engage with all relevant sectoral organizations that may be affected by any proposed measures. This means, at a minimum, that the IA must provide for the LSTC to consider the implications of any proposed measures on activities subject to the competent RFMOs (or other competent organizations) in its assessment of the various proposals. However, more than that, to promote cooperation and coordination, the LSTC could be empowered by the IA to request that relevant RFMOs respond to any objections to a potential conflict with their own management measures and take any such objections into account in making its own recommendation to the COP. There are practical issues connected with this consultation process, in

management of cumulative impacts over both time and geographical is often poorly addressed, or lacking altogether."

${ }^{61}$ Para. 3 of the UN General Assembly Resolution 69/292 (n 2)

${ }^{62}$ Whether proposals are submitted to the Conference of the Parties, which then transmits to the LSTC, or the proposals are submitted directly to the LSTC, is a matter of detail that would be determined in the IA. 
particular the modalities for consultation, which fall outside the scope of this article and which likely can only be addressed in memoranda of understanding with various RFMOs.

Fourth, any recommendation by the LSTC to the COP on the establishment of a MPA should spell out clearly the possible impacts on activities regulated by other organizations, including RFMOs, and the views of such organizations (including the extent to which the RFMO has rejected the measures as in conflict with its own). In making its own decision, in accordance with its own decision-making procedures, the COP should also be required to, together with other factors and the criteria established in the IA, take into account the recommendations from competent organizations. If, having taken into account the relevant factors and criteria, the COP decides to establish an MPA, with measures that might potentially have an impact on the activities regulated by another organization or which would require the cooperation of that organization, the decision of the COP would, inter alia, spell out the nature of the potential impact. In addition, the decision would request the secretariat to bring the decision to the attention of the relevant organization and request its cooperation in giving effect to the decision. For example, if the decision by the COP to establish an MPA would require the imposition of a no-take measure on certain tuna species in the Atlantic Ocean falling under the mandate of ICCAT, the decision would request that ICCAT adopt measures prohibiting the exploitation of such species.

Where the relevant RFMO itself adopts the measures required by the IA, then problems of conflict do not arise. It is only where, for whatever reason, the relevant RFMOs do not accept the measures affecting their areas of competence that questions of conflicts may arise. The recommendation to require comments by RFMOs to be taken into account is precisely to avoid, or at any rate reduce, the incidence of non-support of measures adopted under the IA by RFMOs. Support by the relevant RFMOs would significantly improve implementation and effectiveness of any measures adopted under the IA.

However, the question arises whether in every case the concurrence of RFMOs and other competent organizations is necessary for action. The answer is: whereas concurrence will always be useful, it is hardly always necessary. After all, the decision to establish an MPA by the mechanism under the IA, and the measures adopted thereunder, will be binding on the States Parties to the IA whether or not a comparable decision has been made by another competent organization, such as an RFMO. States Parties to the IA would not be freed from any obligations from implementing the measures just because they also happen to belong to an RFMO which has not adopted the said measure. This point is particularly important, given that it is inconceivable for an RFMO to take a decision obliging states to engage in (destructive) fishing activities such that a conflict arises between obligations under the RFMO and the measure adopted under the IA. At best, there may be incoherence between the obligation under the IA and permissiveness of the RFMO.

A state under an obligation to prevent conduct under the IA is not released from the obligation by virtue of the freedom (or right) under an RFMO to permit such conduct nor can it claim a conflict of obligations. This is because the right to permit conduct is not the same as an obligation to permit conduct. To take, yet again, ICCAT as an example, the establishment by the COP of an MPA in part of the Atlantic Ocean, within the Convention Area of ICCAT, which includes within that MPA a prohibition on the exploitation of, for example, Yellowfin tuna, places an obligation on a State Party to ICCAT to refrain from permitting the vessels under its jurisdiction to catch Yellowfin tuna within said MPA. That such a State Party is permitted to do so under ICCAT measures does not affect its legal obligation under the IA to refrain from fishing (or permitting the fishing for) Yellowfin in this Area. Moreover, there would be no conflict between the measures, because ICCAT does not require but permits the taking of Yellowfin. In this sense, consistent with General Assembly Resolution 69/292, this proposed approach would not 'undermine' the mandate of RFMOs, because it would create conflicting obligations.

As a matter of international law, the only issue that should arise would be the applicability of the measures to non-States Parties to the IA. Non-States Parties to the IA, whether they are members of the relevant RFMO or not, could not be obliged by the said measures where the RFMO has not adopted an equivalent measure. Non-State Parties to the IA who are party to an RFMO would be bound, under the rules of the RFMO, by a measure adopted under the IA which has also been adopted by the RFMO. As a 
matter of international law this latter situation is addressed by the need to obtain the concurrence of the RFMO. Not obtaining the concurrence of the RFMO essentially frees States Parties of RFMOs, who are not also State Parties to the IA, from any obligation under the adopted measures.

The current article is concerned principally with RFMOs. However, an international organization such as the International Seabed Authority (hereinafter the 'ISA') might pose slightly different challenges. The ISA does not merely adopt measures that constrain State behaviour. It itself acts by issuing licenses and permits for prospecting, exploration, and (eventually) exploitation. ${ }^{63}$ However, even here, the principles described above would be applicable. A State Party to the IA would be prevented from engaging in or authorizing an activity prohibited by a measure establishing an MPA under the IA, even if such a measure were approved in accordance with the rules of the ISA. However, the ISA itself and other members of the ISA that are not party to the IA, would not be similarly constrained unless the ISA issued a decision adopting similar measures.

The legal position described above could result in very unsatisfactory results of implementation if the IA does not attract a significant number of ratifications and the RFMOs do not generally support the measures adopted under the IA. In such an eventuality it would mean that a minority of States are obligated to respect the measures, while a large number of States are free to ignore such measures - a recipe for ineffectiveness. This has two policy implications. First, it is imperative that once adopted, the IA attracts a significant number of ratifications from States. Second, all efforts to secure cooperation, coordination and eventually concurrence of other competent international organi zations, including RFMOs, will be very important. In this regard, securing the recognition of the General Assembly in its annual resolutions on the law of the sea (including the fisheries resolution), would also contribute to the increase of the effectiveness of the measures. Finally, it is important to state that, to be effective, the IA would need to place an obligation on States Parties to support, in other fora, the recognition of the measures adopted under the IA. This includes deliberations in RFMOS when the RFMO considers whether or not to support the measures, and also in the consultations on the annual General Assembly resolutions on the law of the sea.

\section{Conclusion}

One of the main concerns raised about a possible IA is the extent to which it would be compatible with existing mechanisms. Whereas the fears are real, from the perspective of international law they should not be overstated. To this extent, UN General Assembly Resolution 69/292 requires that the mandates of existing mechanism not be undermined. Thus, in drafting the new IA, it is important that coordination between existing mechanisms and organizations, on the one hand and, on the other hand, the new IA and the mechanisms established under it with a mandate to establish MPAs, be promoted.

It is argued in this article that the optimal approach to be taken in the design of an IA would be one that recognizes the important role of other organizations, in particular RFMOs, without deferring to them. This would require that the IA be based on a number of key principles. First, RFMOs and other organizations, within the functional and geographic area of competence, should be permitted to make proposals for the establishment of MPAs. Second, RFMOs should, while the proposals are being considered at expert body level, be consulted. Third, any decision to establish an MPA must take into account the views of the relevant RFMOs and request such an RFMO to adopt equivalent measures.

The approach described is, first of all, only illustrative; several other models and variations of the model may exist. Second, it should be recognized that the approach is, because of the structure of international law, necessarily imperfect. It leaves unconstrained states that are party neither to the IA nor to the relevant RFMOs. It also leaves unconstrained states that are party to an RFMO that has not adopted equivalent measures. However, it does provide the potential for cooperation between RFMOs and mechanisms under the IA, and a real prospect for strong measures for conservation and sustainable

\footnotetext{
${ }^{63}$ See Art. 162(2)(j) of the UN Convention on the Law of the Sea. See also, generally Annex III to the UN Convention on the Law of the Sea, Basic Conditions of Prospecting, Exploration and Exploitation.
} 
use of marine biodiversity in areas beyond national jurisdiction. 